\title{
TOWARDS A BETTER KNOWLEDGE OF CANSIGLIO KARST SYSTEM (ITALY): RESULTS OF THE FIRST SUCCESSFUL GROUNDWATER TRACER TEST
}

\author{
PRISPEVEK K BOLJŠEMU POZNAVANJU KRAŠKEGA SISTEMA \\ CANSIGLIO: REZULTATI USPEŠNEGA SLEDILNEGA POSKUSA
}

\author{
Valentina VINCENZI ${ }^{1}$, Alberto RIVA ${ }^{2}$ \& Stefano ROSSETTI ${ }^{3}$
}

\begin{abstract}
UDC 556.34.04(450)

Valentina Vincenzi, Alberto Riva \& Stefano Rossetti: Towards a better knowledge of Cansiglio karst system (Italy): results of the first successful groundwater tracer test

Cansiglio is a limestone plateau located on the border between the regions of Veneto and Friuli-Venezia Giulia, northeastern Italy. The eastern area is characterized by a thick succession of Cretaceous peritidal carbonates, while the central western part is characterized by slope breccia deposits. Even though Pian Cansiglio is an important karst system, its hydrogeology is poorly known. Three important springs that form the Livenza River are located at its southeastern border and are thought to represent the majority of karst aquifer discharge, but no experimental data are available in the literature. Gruppo Speleologico Ferrarese explored an 800 m deep cave (Abisso Col de la Rizza) on Pian Cansiglio, which provided the opportunity to conduct tracer tests. Fluorescent dyes were injected in September 2008 in Abisso Col de la Rizza (uranine) and in Bus della Genziana (tinopal CBS-X). Over a period of three months, local cavers conducted an intense sampling programme, which included collecting water samples, charcoal bags and cotton lints. Automated samplers were used for high frequency monitoring at two of the springs. Tinopal was not detected, so the connection between Bus della Genziana and the springs was not demonstrated. The connection between Abisso Col de la Rizza and two of the springs was demonstrated by uranine. A mean velocity of $248 \mathrm{~m} /$ day results from the tracer concentration peaks; intense rainfall events increased the flow velocities four to five times. Different hypotheses are considered in order to explain the low mass recovery rate ( $32-40 \%$ of the injected mass). The uranine tracer test demonstrated that Pian Cansiglio aquifer contributes to the two Livenza springs; it also opens a question about the third spring, which probably originates from
\end{abstract}

Izvleček

UDK 556.34.04(450)

Valentina Vincenzi, Alberto Riva \& Stefano Rossetti: Prispevek $k$ boljšemu poznavanju kraškega sistema Cansiglio: Rezultati uspešnega sledilnega poskusa

Cansiglio je karbonatna planota $\mathrm{v}$ severovzhodni Italiji, na meji med Furlanijo Julijsko krajino in Benečijo. Vzhodni del območja je sestavljen iz debelega zaporedja krednih obplimskih karbonatov, na zahodnem delu pa prevladuje pobočna breča. Čeprav velja Pian Cansiglio za pomemben kraški sistem, je njegova hidrogeologija slabo poznana. Na jugovzodnem robu območja so trije kraški izviri, ki sestavljajo reko Livenzo. Sicer že dolgo predvidevamo, da ti izviri predstavljajo glavni odtok kraškega masiva, empiričnih dokazov v literaturi ni. Nedavno je jamarska skupina iz Ferrare na Pian Cansigliu raziskala 800 m globoko jamo Abisso de la Rizza. Septembra 2008 smo v to jamo in v jamo Bus della Genziana, injicirali sledila uranin in tinopal (CBS-X). V naslednjih treh mesecih so lokalni jamarji vzorčili vodo, aktivno olje in bombažne kosme. Na dveh izvirih smo namestili tudi avtomatski zajemalnih vzorcev. Tinopala nismo zaznali, tako da povezava med jamo Bus della Genziana in izviri ni dokazana. $\mathrm{V}$ obeh izvirih pa se je pojavil uranin, kar kaže na njihovo povezavo z Abisso Col de la Rizza. Navidezna hitrost, dobljena iz vrhov prebojne krivulje, je $248 \mathrm{~m} / \mathrm{d}$. V obdobju poskusa je bilo štiri do pet padavinskih dogodkov, ki so dodatno povečali hitrost prenosa sledila. Delež povrnjenega sledila je relativno majhen (32-40\%). Test je nedvomno pokazal povezavo Pian Cansiglia z dvema izviroma, medtem ko vprašanje o povezavi s tretjim izvirom ostaja odprto. Slednji se verjetno napaja pretežno iz območja sosednjega masiva Cavallo. Hiter odziv sistema na padavinske dogodke, kaže na veliko ranljivost vodonosnika in pomen podobnih raziskav za njegovo zaščito.

\footnotetext{
${ }^{1}$ Geotema Srl, Via Piangipane 141, int.5 - 44123 Ferrara, Italy, e-mail: vincenzi@geotema.it

${ }^{2}$ Gruppo Grotte "SOLVE” CAI Belluno \& G.E. Plan Consulting, Via Vigne 3 - 44121 Ferrara, Italy, e-mail: alberto.riva@geplan.it

${ }^{3}$ Gruppo Speleologico Ferrarese, Via Canal Bianco, 44124, Ferrara, Italy \& ISOF-CNR c/o Chemistry Department, University of

Ferrara, Via L. Borsari, 46 - 44121 Ferrara, Italy e-mail: rossetti@isof.cnr.it
}

Received/Prejeto: 9.9.2010 
the Mount Cavallo area (another limestone massif close to Pian Cansiglio). The rapid response to rainfall recharge suggests a vulnerability of the spring system, further supporting the importance of conducting a detailed hydrogeological study.

Keywords: Pian Cansiglio, tracer test, uranine, tinopal CBS-X, karst aquifer, Italy.
Klučne besede: Pian Cansiglio, sledilni poskus, uranin, tinopa CBS-X, kraški vodonosnik, Italija.

\section{INTRODUCTION}

Because karst aquifers cannot be reduced to a simple elementary volume that ignores the whole drainage structure, groundwater tracing is a powerful and well developed tool of karst hydrogeology (Ford \& Williams 2007): it enables connections between caves and springs to be assessed, catchment boundaries to be delimited, groundwater flow velocities to be estimated, degree of connections between underground channels/conduits to be inferred, areas of recharge to be determined and sources of pollution to be identified. Furthermore, tracing is a great tool in the hands of speleologists, because it can provide important information about the inaccessible parts of the karst system during explorations (Goldscheider et al. 2008).

Fluorescent dyes have been used to trace underground water for more than 100 years (Käss 1998), both by hydrologists and by speleologists. This project has demonstrated that a collaborative approach between hydrogeology and speleology is an effective approach to further the study of karst science, as in similar recent investigations (Boyer \& Pasquarell 1999; Jeannin et al. 2007; Perrin \& Luetscher 2008; Cabras et al. 2008; Staut \& Auersperger 2006; Gremaud et al. 2009).

The results of such collaboration have contributed towards an improved knowledge on the part of Italian karst science.

Cansiglio is a limestone plateau located on the border between the regions of Veneto and Friuli-Venezia Giulia, northeastern Italy. The region is known for its extensive karstic development as indicated by its epigenic features (dolines, polje), but the extent of hypogean development is relatively unknown. Very few hydrogeological studies have been conducted in this karst area, despite its wide extension and its importance. Various important springs that form the Livenza River are located at the base of its southern hill; although their karst origin is evident, few experimental data about them and their hydrogeological connections with the Pian Cansiglio exist in the literature.

During the last 15 years, Gruppo Speleologico Ferrarese coordinated the speleological explorations that allowed the huge development of a very deep vertical cave (shaft) on Pian Cansiglio (Abisso Col de la Rizza, Fig. 1). Resulting from their interest in testing the possible connection between the cave and the famous Livenza springs, a geological and hydrogeological study was started. A tracer test was organized and was carried out in cooperation with various speleological teams. During the design phase a double tracer test was chosen, with injection of a second tracer in Bus de la Genziana, another deep cave of Pian Cansiglio.

Despite the limited resources (the research project was self-financed by the speleological teams, thus making only the monitoring of Livenza springs possible), the tracer test provided the opportunity to increase hydrogeological knowledge about the Pian Cansiglio

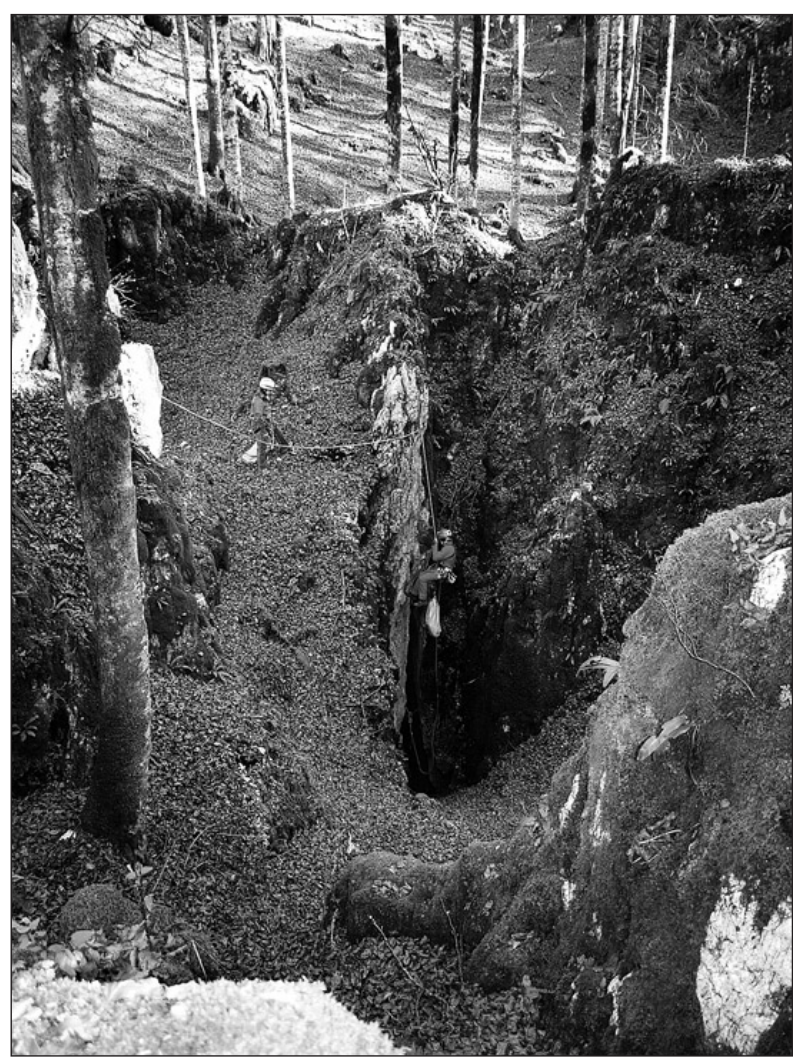

Fig. 1: Abisso Col de la Rizza entrance (Photo: Gruppo Grotte Treviso). 
karst system. At the same time, the great thickness of the unsaturated zone made the help of speleological teams essential for the underground tracer injections and probably for the successful results.

The main goals of the groundwater tracing experiment were to:

- assess the connection between the two caves and Livenza springs;
- assess the transit times between the Pian Cansiglio and the Livenza springs;

- estimate mean flow velocity of groundwater flow;

- infer new knowledge about Cansiglio karst aquifer systems.

\section{GEOLOGY, KARST AND HYDROGEOLOGY OF THE CANSIGLIO PLATEAU}

\section{GEOGRAPHICAL AND GEOLOGICAL SETTING}

The Cansiglio Plateau is a quite wide polje located in the Western Carnic Prealps, limited to the west by the Val Lapisina, to the north by the Alpago basin, to the east by Mount Cavallo, and to the southeast and south by the Friuli-Veneto plain. The quadrilateral shape characterises the general arrangement, stretched along the NE-SW axis with a wide depression in the centre (Fig. 2). The altitude is around $1000 \mathrm{~m}$ asl, limited on the $\mathrm{W}-\mathrm{SW}$ side by ridges of approximately $1300 \mathrm{~m}$ asl. The most elevated heights are Mount Millifret (1577 m) and Mount Pizzoc (1565 m). To the E-SE the heights are around 1350-1400 m, with the maximum at Mount Croseraz (1694 m).

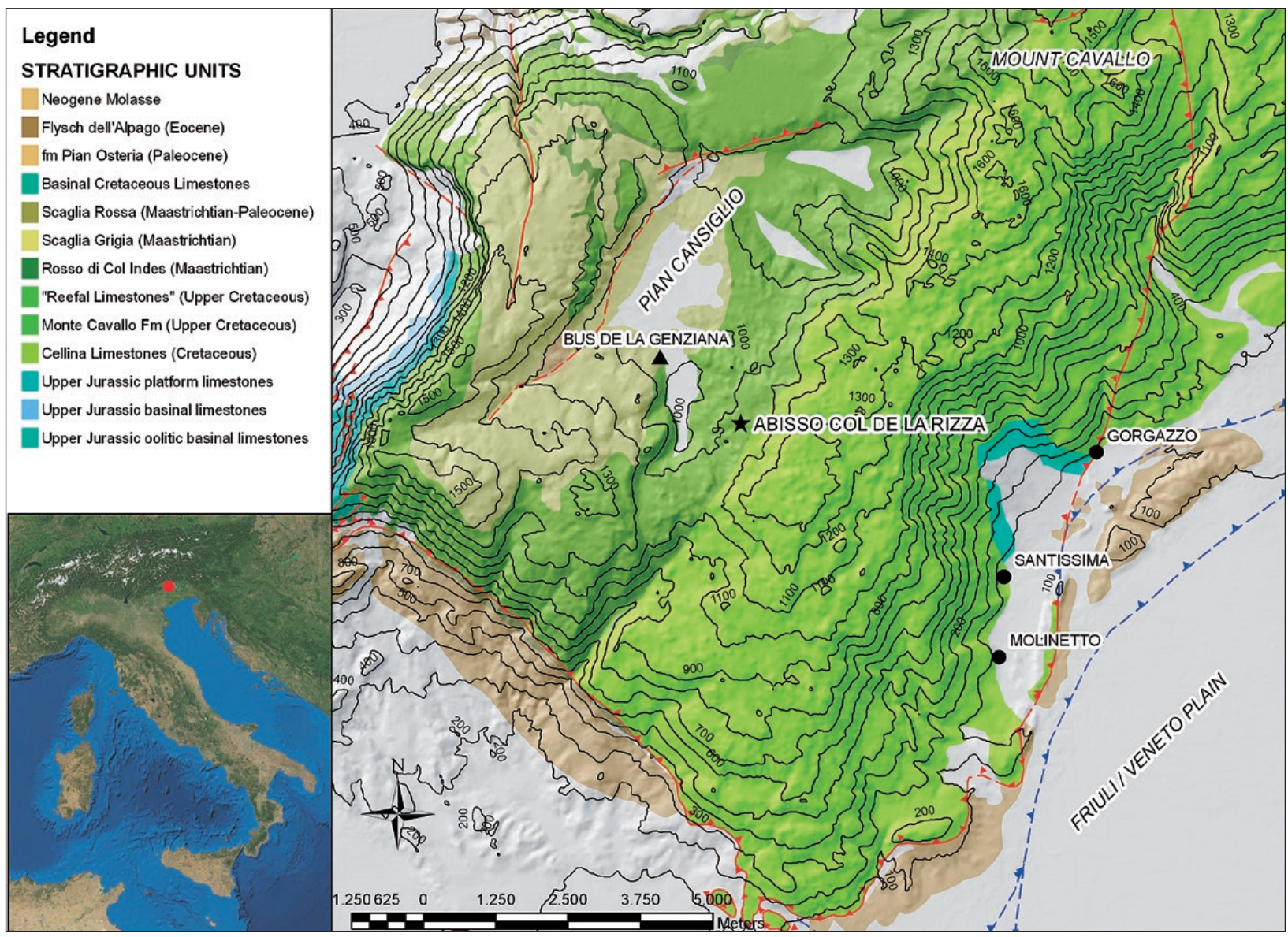

Fig. 2: Geological sketch of the main stratigraphic units cropping out in the area of Pian Cansiglio, with the location of the studied caves (triangle and star) and the monitored springs (black dots). 
These ridges that enclose the basin are interrupted on the northern side by a wide opening in the locality of Campon $(1045 \mathrm{~m})$ and in the south in the locality of Crosetta $(1118 \mathrm{~m})$. The basin is occupied by a wide depression called Pian Cansiglio and by two other depressions in the northeastern side, Valmenera and Cornesega (minimum heights 907 and $898 \mathrm{~m}$ asl, respectively).

A geological outline of Cansiglio Plateau is available in Cancian et al. (1985). The outcropping rocks range in age from Upper Jurassic to Paleocene, and are mainly composed of carbonates. The eastern area is characterized by a thick succession of Cretaceous peritidal carbonates (Cellina Limestones), while the central western part is characterized by slope breccia deposits (Fadalto Formation and Mount Cavallo Formation), all capped by basinal marly carbonates (Scaglia Formation; Cancian et al. 1985, Riva 2000).

In the plateau karst features are quite well developed, as described in the next section. The main caves of the area cross the stratigraphic succession down to the Lowermost Cretaceous. In particular, the Bus de la Genziana stratigraphy has been described in detail by Cancian and Ghetti (1989) and Riva (2000). The Abisso Col de la Rizza is located in an unusual position, exactly at the edge of the Cretaceous Friuli Platform, just a few meters downslope.

The plateau is bounded at the southeast by a regional thrust fault (Caneva Line) with a vertical displacement of more than $4000 \mathrm{~m}$ (Cavallin 1979). This thrust faulting resulted in a relatively wide asymmetric anticline (Cansiglio Anticline) in the hanging-wall, with steep dipping beds near the main fault. The main thrust plane is also associated with minor faults developing a quite wide cataclastic zone, about $500 \mathrm{~m}$ in width. The main karst springs occur in the lower limb of the anticline, where the tectonized Mesozoic limestones (Upper Jurassic Polcenigo Limestone and Cretaceous Cellina Limestones) are in tectonic contact with the Cenozoic and Quaternary impermeable units of the footwall. Active tectonic movements are documented by geophysical measurements (Braitenberg et al. 2007) and by neotectonic features observed in some caves of the plateau (Bus del Pal and Bus de la Genziana caves, Riva 2000).

\section{KARST FEATURES}

The morphology of the entire plateau is a typical karst, better developed in the southeast, where limestones crop out. Morphology is smoother to the north, where the marly carbonates crop out.

The Pian Cansiglio is a wide polje, where dolines are the most typical landscape features, both of dissolutional and/or collapse origin (Castiglioni 1964). Karst features are more evident in the flat areas of Pian Cansiglio, al- though the most developed superficial karst features are located inside the Cansiglio Forest, with subcutaneous karrens, coupled with fissures and small shafts. There is a general absence of surface water drainage, except for the zones where thick Pleistocene-Holocene deposits occur (Girardi \& Toniello 1983).

In the area some hundreds of caves have been discovered, few of which are deeper than $100 \mathrm{~m}$. They are mostly represented by deep shafts, i.e. caves with a predominantly vertical development. The most famous one is the "Bus de La Lum", located at the southwestern margin of the plateau: the Commissione Grotte of Società Alpina delle Giulie has conducted exploration in the system since 1924 to depths of $180 \mathrm{~m}$ with a $175 \mathrm{~m}$ deep shaft terminating at a break down area.

Abisso Col de la Rizza (A) is a cave located near the Rizza hill inside Cansiglio Forest (entrance at 1107 $\mathrm{m}$ asl), and was first discovered by Società Alpina delle Giulie in 1957, when the entrance pit was descended. In 1994, during a survey in the area of Candaglia, Gruppo Speleologico Ferrarese discovered an additional $50 \mathrm{~m}$ of passage, providing the next stage of explorations. After a couple of years, the exploring process stopped for other targets. In 2003 the team started new surveys, finding an important extension, leading to more than $4 \mathrm{~km}$ of passage, achieving a maximum depth of $793 \mathrm{~m} \mathrm{bgl}$ (where a sump occurs). Explorations are going on, in cooperation with various Italian speleological teams.

Currently, this shaft is the deepest of the area. It consists of Cellina limestones. At the depth of $150 \mathrm{~m} \mathrm{bgl}$ a wide area occurs, developed in the horizontal direction. Then it develops with tight spaces, separating in 3 different ways and reaching the depths of $793 \mathrm{~m}, 340 \mathrm{~m}$ and $340 \mathrm{~m}$ bgl. Numerous stream ways flow inside the cave, with an average flow rate of 1-2 1/s. One year of temperature monitoring data, performed inside the cave by Gruppo Speleologico Ferrarese with temperature sensors (sensitivity of $0.01^{\circ} \mathrm{C}$ and accuracy of $0.06^{\circ} \mathrm{C}$ ), indicates that the mean annual temperature varies between $2.7^{\circ} \mathrm{C}$ at the end of the first shaft $(100 \mathrm{~m} \mathrm{bgl})$ and $5.2^{\circ} \mathrm{C}$ at $200 \mathrm{~m}$ bgl. Mean annual air temperature outside, registered for four years at the meteoric station of Tramedere (ARPAV data), is $6.5^{\circ} \mathrm{C}$.

Bus de la Genziana (B) is a complex cave formed by galleries and shafts and was discovered in the 1960s during the widening of the national road no. 622 . The entrance is located at $1000 \mathrm{~m}$ asl. It develops in the Cretaceous slope carbonates, reaching a depth of $588 \mathrm{~m}$ with an extension of more than $5 \mathrm{~km}$ in different levels. Current explorations are concentrated on some horizontal levels, probably of phreatic origin, at a depth of $90 \mathrm{~m} \mathrm{bgl}$. At this depth there are also some fossil passages, filled with sands and dark brown silt and clays, documenting 
a polyphased development of the cave: in these deposits it is possible to find clasts of rocks that now are not cropping out on the Pian Cansiglio (Riva 2000).

Active water circulation is documented from a depth of about $100 \mathrm{~m}$, where a perennial stream crosses some galleries and disappears at about $150 \mathrm{~m}$ bgl. The water circulation reappears at a depth of $220 \mathrm{~m} \mathrm{bgl}$, where the stream flows in an impressive underground canyon, then disappears down a small hole, just a few tens of meters before the sump that marks the base of the cave. The walls of the lowermost galleries are partially covered by soft brown clay that documents the temporary flooding of this portion of the cave; in fact during floods the cave stream fills to a depth of $100 \mathrm{~m}$.

\section{HYDROGEOLOGY OF PIAN CANSIGLIO}

It is universally recognized that Pian Cansiglio represents an important and interesting karst aquifer, but relatively few hydrogeological studies are available in the literature, and have often been made with naturalistic approaches or didactic purposes. The poor hydrogeological knowledge is probably related to the general geological complexity of the area. The plateau is subdivided by two administrative regions; as a result there are no general descriptions available on the stratigraphy or hydrogeology.

The Environmental Protection Agencies of the two regions recognize the importance of this karst system and a hydrogeological outline is available in ARPA FVG (2006) and ARPAV (2007): the Cansiglio-Cavallo massif is described as a karst system characterized by diffusive groundwater circulation, due to the high density of dolines and swallow holes on the plane, and by very deep karst conduits, typical of mature karst systems. But no experimental data exist that can confirm these hypotheses.

In ARPA FVG (2006) the Cansiglio-Cavallo massif is inferred to flow towards Santa Croce Lake, along its western boundary (Veneto Region), and to the springs of Livenza River, on the southeastern side (Friuli Venezia Giulia Region). However the hydrologic connection with Santa Croce Lake has never been demonstrated.

On the contrary, it is almost certain that Livenza springs take origin from the Cansiglio massif. The three major springs are located at the southeastern border of the plateau: Santissima spring $(S)$ and Molinetto spring $(\mathrm{M})$, located at $36 \mathrm{~m}$ asl, and Gorgazzo spring $(\mathrm{G})$ at $57 \mathrm{~m}$ asl (see Fig. 2 for the location on the maps and Fig. 3 for the photographs). Even though their karst nature is evident (huge flow rates that react rapidly to rainfall events), few data exist in the literature about them, and the connection between Pian Cansiglio or Monte Cavallo has never been directly demonstrated.

Santissima and Molinetto are located in the Palù valley, which develops in a NE-SW direction, interposed

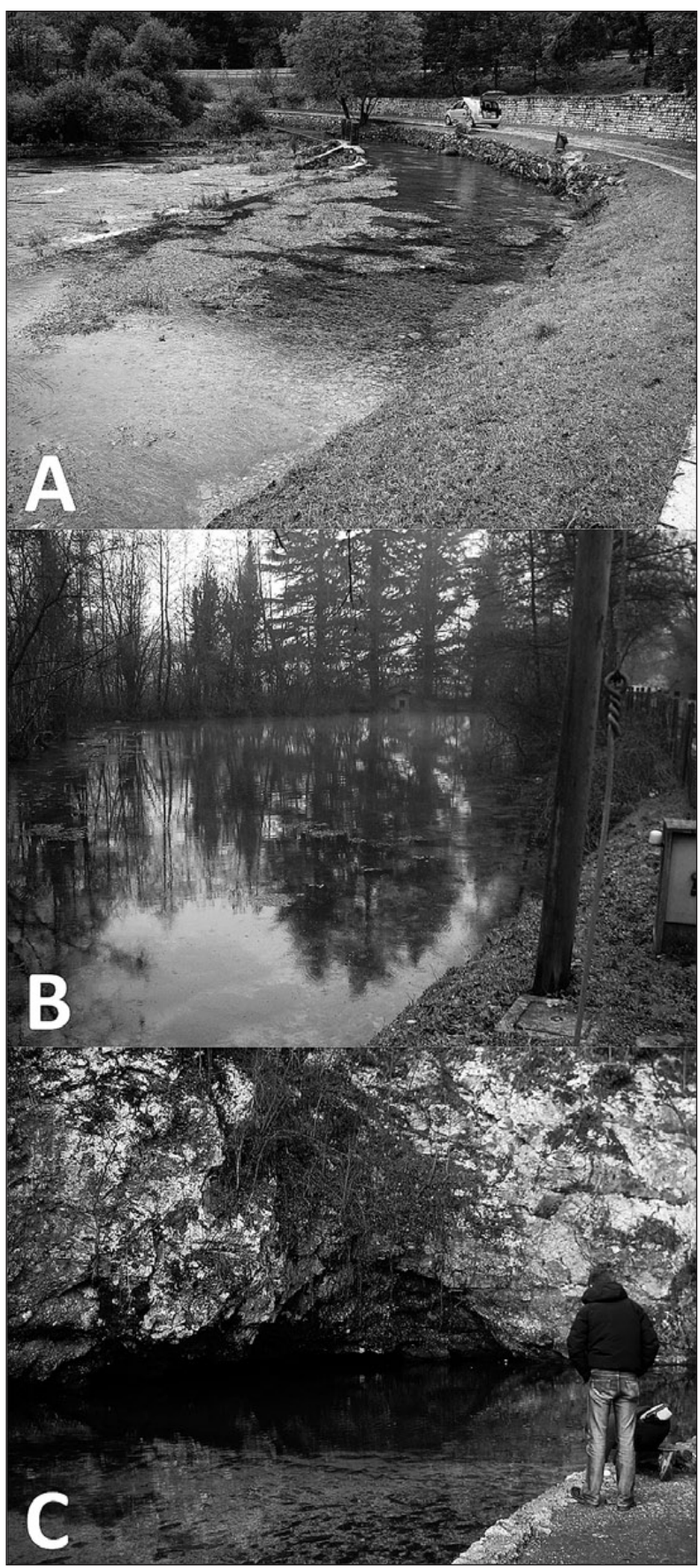

Fig. 3: Livenza springs: a) Santissima, b) Molinetto, c) Gorgazzo (Photos: V. Vincenzi).

between the Cansiglio massif and the small hills that connect the mountains to the plain. The groundwater outflow is diffuse, with many small spring pools at the base of the rocks, pouring into a large, marshy basin, partially reclaimed. Santissima is partially exploited for public water supply, and Molinetto is used for fish breeding. Gorgazzo spring is quite different, because it is a vauclusian spring, coming out from a limestone outcrop; 
subaqueous explorations by Luigi Casati in 2008 reached $212 \mathrm{~m} \mathrm{bgl}(155 \mathrm{~m} \mathrm{bsl})$, where the siphon continues, and a horizontal distance of $440 \mathrm{~m}$ from the entrance (Prometeo Ricerche per l'Uomo 2008). This spring is not exploited, but it represents an important local tourist site for its peculiar beauty. The average total flow rate of the three springs is reported from about $11 \mathrm{~m}^{3} / \mathrm{s}$ (Meneghel et al. 1986): Santissima is more than $6 \mathrm{~m}^{3} / \mathrm{s}$ (Cucchi et al. 1998), Gorgazzo about $3 \mathrm{~m}^{3} / \mathrm{s}$ and Molinetto less than $2 \mathrm{~m}^{3} / \mathrm{s}$ (Vianelli 2000).

Some recent studies analyzed the hydrochemical composition and environmental isotopes of Livenza springs (Cucchi et al. 1998, ARPA FVG 2006, Grillo 2007): spring waters are consistent with the alkaline facies, very poor in $\mathrm{Mg}$ ions, due to the absence of dolomites in the carbonate sequence. Isotopic ratios of oxy- gen-18 and deuterium at Santissima springs, monitored over four years, indicate long and deep flow pathways, and a composed drainage system, with interconnected drains. Isotopic composition variation is minor relative to seasonal flux; this issue, together with the huge mean flow rates and the long recession phase of the spring, suggests the presence of an important base flow and of an extensive recharge area. The average elevation of the recharge area calculated through isotopes results in about $1000 \mathrm{~m}$ asl; that is the average elevation of Pian Cansiglio polje.

In Grillo (2007) Livenza springs are also compared to infiltration waters at different depths in three caves of Pian Cansiglio: both hydrochemical facies and isotopic composition are very similar, suggesting that they pertain to the same groundwater flow system.

\section{MATERIALS AND METHODS}

\section{TRACER INJECTIONS}

Two different fluorescent dyes were selected as tracers because of their favourable properties and proven safety (Behrens et al. 2001). Uranine (CAS 518-47-8) is the most conservative fluorescent dye (Käss 1998); tinopal CBS-X (CAS 54351-85-8) avoids interference problems with the first one during analyses, and is widely used in Italy in speleological investigations, mainly for its low cost and for the light colour.

The injection mass of uranine has been estimated starting from an empirical formula, available in Käss (1998), based mainly on distances, detection limit $\left(10^{-3} \mathrm{ppb}\right)$ and spring flow rates; but the high uncertainty about karst type, groundwater velocities and other parameters of this formula induced a great variability range, from grams to tens of kilograms; a value of $5 \mathrm{~kg}$ has been decided after applying the authors' hydrogeological sensitivity, in order to avoid colour problems at Santissima spring, used for public water supply. The quantity of tinopal should have been 100 times higher than uranine, considering its higher analytical detection limit $\left(10^{-1} \mathrm{ppb}\right)$, but this was clearly impossible and, also due to its lower solubility in water, $10 \mathrm{~kg}$ was the maximum quantity affordable.

On 20 September 2008 the two tracers were injected inside two of the most important caves of Pian Cansiglio (for the location see Fig. 2). At about 3:00 pm, $10 \mathrm{~kg}$ of tinopal CBS-X were injected inside Bus de la Genziana by speleologists at a depth of $120 \mathrm{~m} \mathrm{bgl}(880 \mathrm{~m}$ asl); powder tracer was dissolved on site, inside the cave, taking advantage of a small waterfall and a small water pool.
Uranine was previously prepared in the laboratory by dilution of $5 \mathrm{~kg}$ of powder tracer with $15 \mathrm{~L}$ of water. At 5:00 pm the $0.333 \mathrm{~g} / \mathrm{L}$ uranine solution was injected inside Abisso Col de la Rizza by speleologists at a depth of $270 \mathrm{bgl}(837 \mathrm{~m}$ asl).

\section{SAMPLING SURVEYS}

Monitoring at the three springs included both discrete water sampling (manually and with auto-samplers) and accumulative sampling by means of activated charcoal bags (for uranine detection at low concentration) and cotton lints for tinopal adsorption. Considering the huge dimensions of the springs (Fig. 3), in order to be sure of a representative sampling process, three to four sampling locations were chosen at every spring: one point where water outflows, another one where all the spring waters are canalized, and one to two at intermediate positions. Two automated samplers were also used for a high frequency monitoring at two of the springs ( $G$ and $M$ ): they were located where the total waters are canalized, and they collected three water samples per day during the first five weeks after injections, in case of sudden arrivals and steep breakthrough curves (BTCs). After a first background sampling before injections, performed on $18 / 09 / 2008$, an intense sampling programme started the day after injections and lasted for 3 months (until 12/12/2008): 33 sampling surveys have been performed, with a progressively decreasing frequency. 


\section{LABORATORY ANALYSES}

The samples were analysed with the spectrofluorometer (PerkinElmer LS 45) of the Earth Sciences Department of Ferrara. As waters were characterized by a $\mathrm{pH}>7$, it was not necessary to add a basic buffer to the water samples. Charcoal samples were dried, dipped in an eluent for $12-14 \mathrm{~h}(10 \mathrm{~g} \mathrm{KOH}$ per $100 \mathrm{ml}$ of $96 \%$ ethanol) and then analysed with the spectrofluorometer (Käss 1998, Vincenzi et al. 2009).

\section{EVALUATION OF BREAKTHROUGH CURVES AND RECOVERY RATES}

Tracer results are presented as concentration-time data, i.e. breakthrough curves. Basic parameters were directly obtained from the BTCs: first detection time $(t 1)$, peak time $(t p)$, peak concentration $(C p)$, and the corresponding maximum velocity (Vmax) and peak velocity $(V p)$. The minimum three-dimensional distances between the cave and the spring were taken as relevant flowpath length $(L)$.
Breakthrough curves are then compared to rainfall data gathered by ARPAV at the meteoric station "Cansiglio Tremedere" (ID 216, X 1764055, Y 5108352, GBRome 1940, elevation $1028 \mathrm{~m}$ asl).

Tracer recovery rates $(R)$ were calculated as a function of the variable discharge $(Q)$. Unfortunately it was not possible to measure directly spring flow rates, due to the huge water volumes (Fig. 3) and the lack of tempo$\mathrm{ral} / \mathrm{economic}$ resources. From the values of minimum, maximum and average flow rates found in literature (Vianelli 2000) two scenarios of discharge vs. time at the two springs (see graphs in Fig. 5a) have been used to calculate the recovered mass of uranine at the two springs.

\section{LINEAMENT ANALYSIS}

In order to analyze the influence of tectonic features and fracture distribution on karst development and groundwater flow, a lineament analysis on Landsat ETM+ imagery regarding the Cansiglio area has been performed.

\section{TRACER TEST RESULTS}

\section{BREAKTHROUGH CURVES}

Uranine, injected on 20/09/2008 inside Abisso Col de la Rizza, was detected at two of the three monitored springs: Santissima and Molinetto. Tinopal was not detected at any of the springs, so hereafter only uranine results are presented. The detection limit of the analytical method used for uranine analyses was $0.0045 \mathrm{ppb}$. That is a good result, considering that in the literature the mini- mum detection limit reported for uranine is $0.001 \mathrm{ppb}$ (Käss 1998; Goldscheider et al. 2008). The effectiveness of the sampling network and frequency is demonstrated by the similar concentrations detected at different points of the same spring (S1, S3 and M1, M3) and by the similar shape of the breakthrough curves reconstructed by means of automated and manual sampling at Molinetto spring (Fig. 4b).

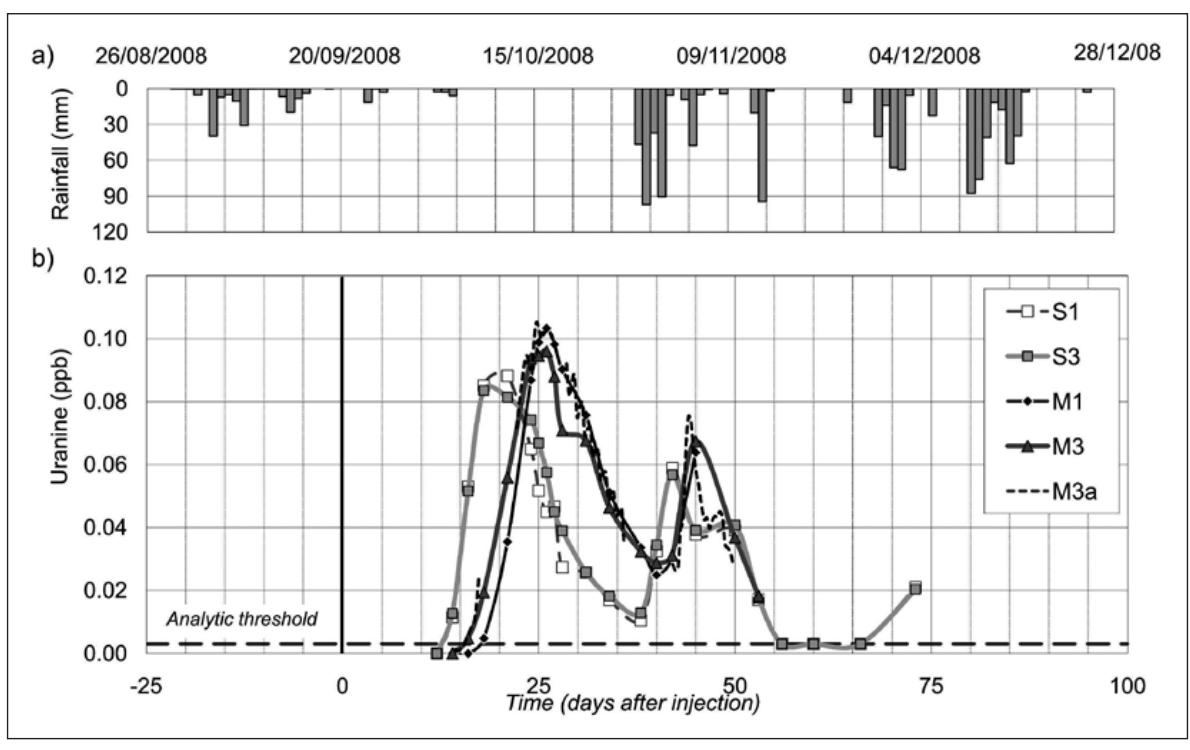

Fig. 4: a) Rainfall data during tracing experiment, compared with: b) breakthrough curves at all the sampling points in which uranine has been detected. The graph shows the good quality of the sampling work: on one hand, different sampling points of the same spring give the same concentration results; on the other hand, the automated sampling at M3 point (M3a) demonstrates the goodness of the manual sampling frequency. 
The tracing experiment started at the end of the dry season, during the recession phase of groundwater, as demonstrated by the progressive decreasing of Gorgazzo spring, where the flow disappeared one month after the injection. On 28/10/2008 the rainy season started, with important rainfall events on Pian Cansiglio. About 24 hours after the intense rains, flow rates at the three springs started increasing significantly, reaching a maxi- mum some days after. At Gorgazzo spring, the flux reactivated the day after the first rainfall events. Rainfall data are presented in Fig. 4a and Fig. 5a for comparison with breakthrough curves, which are strongly influenced by climatic conditions. In fact, a second peak in the breakthrough curves of uranine at both the springs was generated by these important rainfall events, which mobilized the tracer left in the caves.

Results have been analyzed in terms of average concentrations between the two manual sampling points and are presented in Fig. 5, Tab. 1 and Tab. 2, and described hereafter. The first positive water samples were collected at Santissima Spring (S) 14 days after injection; the next day uranine started to be detected also in water samples collected at Molinetto spring (M): the maximum velocity values resulted respectively in 384 and $389 \mathrm{~m} /$ day.

A concentration peak of $0.084 \mathrm{ppb}$ arrived at $\mathrm{S}$ spring 20 days after injection, indicating a mean velocity of 256 $\mathrm{m}$ /day. A slightly higher concentration peak arrived at $\mathrm{M}$ spring 26 days after injection, giving a similar mean velocity value $(240 \mathrm{~m} /$ day $)$. The minimum three-dimensional distances from Abisso Col de la Rizza are slightly different (Tab. 1), but it is more probable that the flow pathway is unique for most of the distance and that it divides in different flow paths only close to the springs outflow.

These mean velocity values can be considered representative of low groundwater level conditions for the karst system, because the tracing experiment started at the end of the dry season, and these first peaks are not disturbed by the starting of rainfall events. 
Tab. 1: Tracer test results: essential data of the three springs are presented; results of tracing with uranine are presented for Santissima and Molinetto springs, in terms of distances, velocities, concentrations.

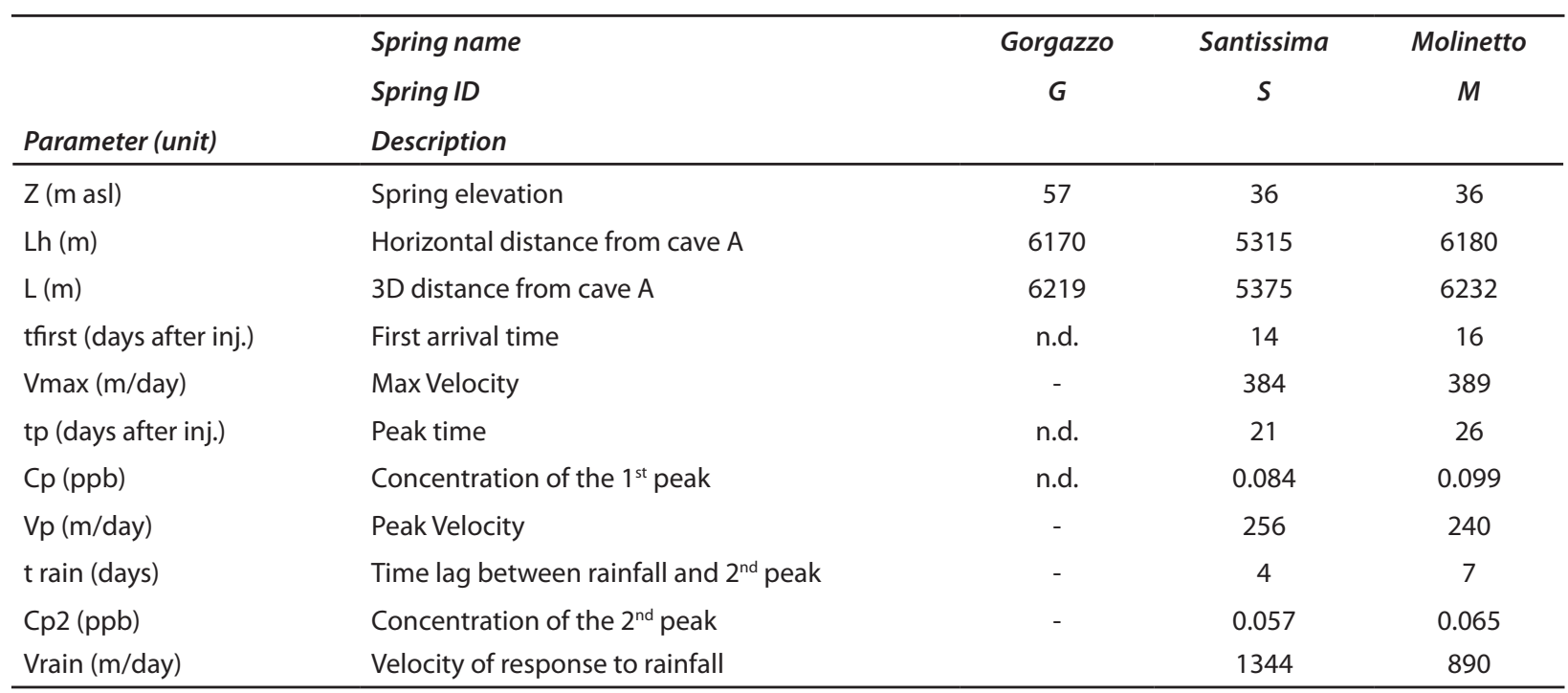

The process of groundwater flow re-activation induced by rainfall events can be considered as a second instantaneous uranine injection, because before the rainfall the breakthrough curves of uranine had almost reached the end of their tails. Calculating the time-lag between the first rainy day and the second uranine peak, velocity values representative of the high-flood event can be calculated. The tracer transport reacts to the rain events with a time-lag of four and seven days respectively at Santissima and Molinetto spring, corresponding to velocities of 1344 and $890 \mathrm{~m} /$ day (Tab. 1): during high flow conditions the two springs present different behaviours, probably due to the activation of different conduit networks or due to erroneous estimates of flow rates. The peak concentration has the same magnitude order as the first peak, indicating that a lot of tracer mass remained in the unsaturated zone after injection, and the rainfall mobilized a considerable quantity of uranine, as the recovery calculations demonstrate.

\section{RECOVERY RATES}

As illustrated in the methodology section, the lack of temporal/economic resources did not allow flow rate monitoring at the springs. So, only estimates of uranine recovery rates have been possible, taking into consideration the two scenarios of discharge vs. time extrapolated from the literature (Vianelli 2000) and presented in the graphs of Fig. 5a. Even if the obtained results only give the magnitude order of the recovered mass, the authors consider them very useful, because this is the first successful tracer test in the Cansiglio-Cavallo karst system, and even approximate numbers can represent very important references, e.g. during the planning of future tracer tests or hydrogeological studies.

The results of calculations for the two scenarios of discharge data are presented in Tab. 2 and graphically shown in Fig. 5b and 5c. The second one is considered more realistic, because it reproduces in a simplified way the response of springs to rain events. Mass recovery val-

Tab. 2: Estimates of uranine recovery rates at Santissima and Molinetto springs, as a function of the flow rate model scheme, as illustrated in Fig. 5: two different phases are distinguished, before and after the starting of rainfall events.

\begin{tabular}{|c|c|c|c|c|c|c|c|}
\hline \multirow[b]{2}{*}{ Parameter (unit) } & \multirow{2}{*}{$\begin{array}{l}\text { Spring name } \\
\text { Spring ID } \\
\text { Flow rate scheme }\end{array}$} & \multicolumn{2}{|c|}{$\begin{array}{c}\text { Santissima } \\
S\end{array}$} & \multicolumn{2}{|c|}{$\begin{array}{c}\text { Molinetto } \\
\text { M }\end{array}$} & \multicolumn{2}{|c|}{$\begin{array}{c}\text { Sum of the } \\
2 \text { springs }\end{array}$} \\
\hline & & 1 & 2 & 1 & 2 & 1 & 2 \\
\hline $\mathrm{R} 1$ (g) & \multirow{2}{*}{ Mass recovered - dry phase } & 608 & 428 & 325 & 220 & 933 & 648 \\
\hline R1\% (\%) & & 12 & 9 & 7 & 4 & 19 & 13 \\
\hline $\mathrm{R} 2$ (g) & \multirow{2}{*}{ Mass recovered - rain phase } & 619 & 570 & 407 & 373 & 1026 & 943 \\
\hline R2\% (\%) & & 12 & 11 & 8 & 7 & 20 & 19 \\
\hline Rtot (g) & \multirow{2}{*}{ Total mass recovered } & 1227 & 998 & 732 & 593 & 1959 & 1591 \\
\hline Rtot\% (\%) & & 25 & 20 & 15 & 12 & 40 & 32 \\
\hline
\end{tabular}


ues have been calculated separately for the dry season (until 27/10) and for the rainy season (from 28/10), in order to estimate the two different contributions. The mass recovered during the dry phase at $\mathrm{S}$ and $\mathrm{M}$ springs is about, respectively, $9-12 \%$ and $4-7 \%$ of the total injected mass. The mass recovered after the flow reactivation induced by rainfalls is slightly higher, about $11-12 \%$ and $7-8 \%$ respectively. Considering that the flow rates of the flood event have been estimated from average values found in literature, it is very probable that they underestimate the flow rates, because the considered rainfall event was quite extreme and all the springs were in high flood conditions (according to the opinion of local people). This means that the mass recovered during the second phase may have been much higher. As a result, the total mass recovered at the two springs is estimated between 32 and $40 \%$ of the injected uranine.

\section{INFLUENCE OF TECTONIC FEATURES ON THE KARST AQUIFER}

The alignment of the three springs at the border of Pian Cansiglio is a very clear example of the influence of tec- tonic features on groundwater flow. It is related to the crop out of an impermeable threshold located below the limestone massif and represented by Cenozoic impermeable units in the footwall of the Caneva Line.

Concerning the underground flow inside the slope carbonates, the only discontinuities controlling the hydrogeologic pattern are the fractures, often organized in fracture corridors, and minor faults. From general observations based on cave descriptions and maps, it can be inferred that the fracture pattern is the factor that strongly controls cave development, while stratigraphic setting plays only a secondary role. The situation changes towards the southeast part of the plateau, where the wellbedded Cellina Limestones are partially conditioning the groundwater flow along bedding planes, especially where strata dip is not horizontal.

Fracturation of rock massifs plays an important role near the Molinetto and Santissima springs, where carbonates are strongly cataclastic: this feature increases the permeability and permits a mainly diffuse flow. This is confirmed by the tracer test results: uranine has been detected only at these two springs, probably due to the

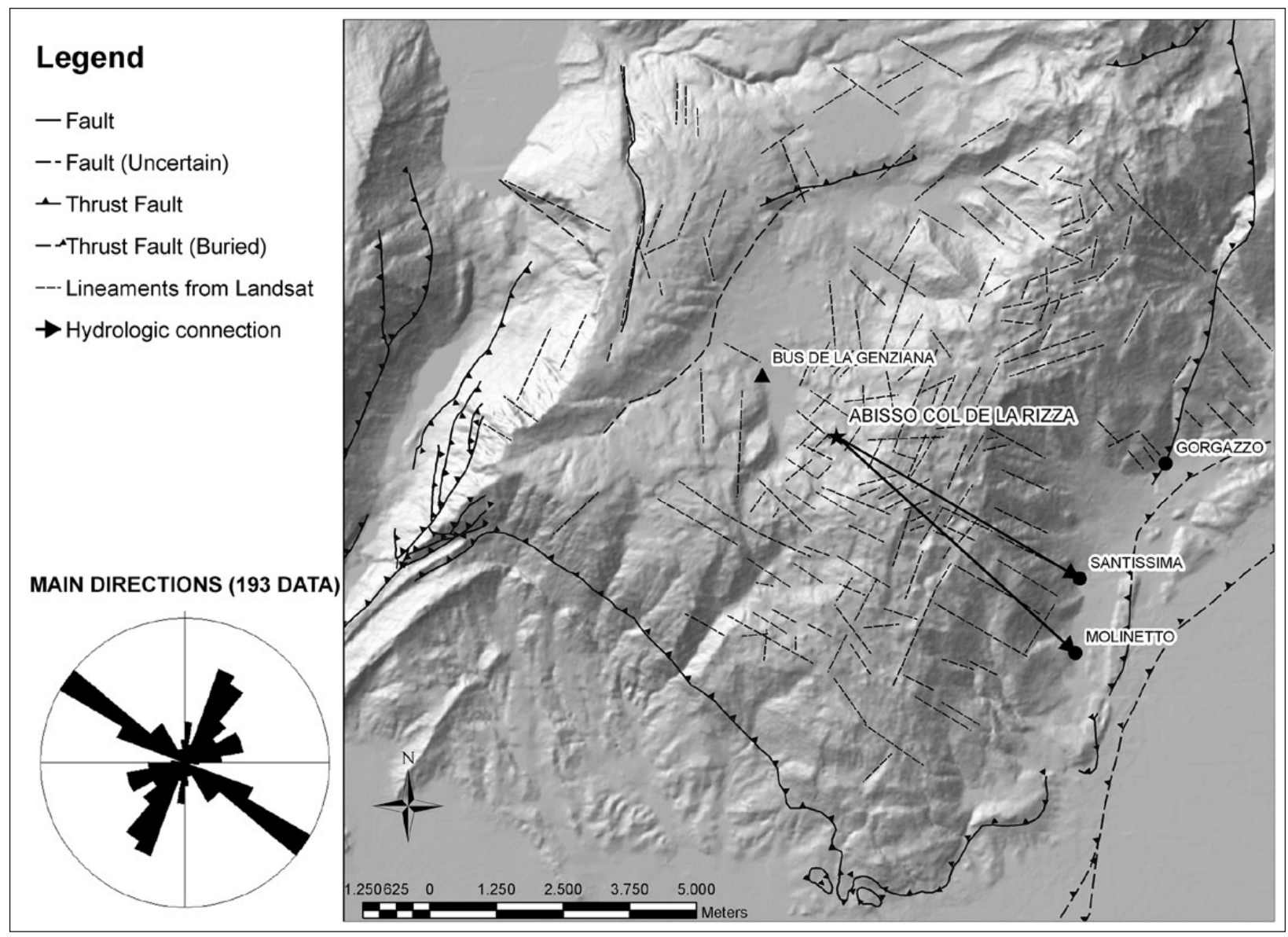

Fig. 6: Tectonic sketch of the area with the main lineaments identified using Landsat ETM+ imagery. The main lineament pattern is similar to the regional tectonic features. 
locally higher permeability that makes the underground flow converge here.

The results of the lineament analysis on Landsat ETM+ imagery are presented in Fig. 6: 193 lineaments are plotted on the stereo diagram and the main lineaments family results along the NW-SE direction, followed by the NNE-SSW. These main directions were recognized also in some caves of the area (Bus del Pal, Bus de la Genziana, Toniello 1973). The first direction (NW-SE) is perpendicular to the Cansiglio Anticline axis and parallel to the Montaner Line, a strike-slip fault bounding the southwestern part of the Cansiglio Plateau. It coincides exactly with the alignment between Abisso Col de la Rizza and Santissima spring, and a quite regu- lar pattern of lineaments occurs between them, suggesting a possible connection. The Bus de la Genziana shows a similar pattern, but groundwater flow is pointing toward the northwest: this feature can be related also to the neotectonic tilting of the northern flank of the Cansiglio Anticline.

Upstream of Gorgazzo spring, located exactly on the thrust line, a few lineaments have been identified. The alignment Abisso Col de la Rizza-Gorgazzo is W-E oriented and does not coincide with a fracture family. All these considerations, together with its location and elevation (about $20 \mathrm{~m}$ higher than the two other springs) suggest that it probably originates from the Mount Cavallo area.

\section{DISCUSSION AND CONCLUSION}

The connection between Abisso Col de la Rizza and Santissima and Molinetto springs was clearly demonstrated. The connection between Bus de la Genziana and the springs was not demonstrated, perhaps due to its absence, or more probably due to the less conservative behaviour of tinopal, with respect to uranine. In multi-tracer tests with fluorescent dyes the different properties of the used substances represent an advantage because they can be optically separated, but also a limitation because the information they provide can not be completely compared due to the different chemical nature (Goldscheider et al. 2008; Vincenzi et al. 2009). In other words, groundwater tracing in Bus de la Genziana should be repeated with uranine in order to exclude the possibility of a connection with the springs.

Uranine provided good results, arriving at very low concentrations (no water colouring problems and no alert problems at Santissima aqueduct occurred), but sufficiently high to allow tracer detection with qualified laboratory analyses. At the same time, a quite good recovery rate $(32-40 \%)$ has been reached, despite the monitoring of only three springs located on one side of the karst plateau. Possible reasons for this partial recovery rate of uranine are, in order of probability: mass loss along the underground path in the thick unsaturated zone, between the injection point and the groundwater level; mass loss in the saturated zone if different flow lines start below the injection point and take the tracer in different directions; tracer dispersion towards different buried springs aligned along the thrust; underestimation of flow rates at the two springs; detection of uranine limited by its concentration very close to the analytical threshold.
An important issue arises from the results: the three springs do not represent a unique discharge point from the system, as frequently reported in the literature (ARPAV 2007; ARPA FVG 2006, Cucchi et al. 1998). The almost identical responses of Santissima and Molinetto springs to recharge events in terms of uranine breakthrough curves and the total absence of uranine at Gorgazzo spring suggest the hypothesis that this last spring probably originates from Mount Cavallo, a conclusion strengthened by lineament and tectonic analysis. The structure of this spring and its elevation, 20 meters above the other two, could suggest that it activates only in overflow conditions, confirmed by its dryness in low flow conditions (at the end of the dry season). But the absence of uranine even after the rainfall events (which caused a new uranine peak at Santissima and Molinetto) permit us to exclude its connection with the Abisso Col de la Rizza.

The connection between Pian Cansiglio and Santissima - Molinetto springs and the fast response to rainfall events are evidence of the high vulnerability of Livenza springs and the important difference between the hydrographic and hydrogeological watershed of the Livenza River. This issue, together with the division of the karst system between two administrative regions (with the recharge zone on one side and discharge springs on the other) could lead to great problems of risk management in case of aquifer contamination.

The authors hope that the results of the present study could represent a starting point for planning a complete research programme on the Cansiglio-Cavallo karst aquifer system, which is essential for good protection of groundwater resources. 


\section{ACKNOWLEDGEMENTS}

First of all we wish to acknowledge people who directly contributed to the tracer test with their voluntary work of sampling at the Livenza springs: Costantino Bottoli (GSS), Flavio Canton e Sonia Dussin (USP), Vladimiro Toniello (GS CAI VV), Fabrizia Cavallari and Massimiliano Montanari. Thanks to the Earth Sciences Department of the University of Ferrara, particularly to Prof. Alessandro Gargini for making available technical instrumentation and to Fabrizia Cavallari for intense laboratory work. A great thanks goes to all the speleological teams who contributed with their interest and their resources to the realization of the test: Gruppo Speleologico Ferrarese, Unione Speleologica Pordenonese, Gruppo Speleologico Sacile, Gruppo Grotte Solve CAI Belluno, Gruppo Speleologico CAI Vittorio Veneto. Particularly, thanks to the speleological teams who contributed to the Abisso Col de la Rizza explorations: Gruppo Spelelogico Ferrarese, Gruppo Speleologico Urbinate, Gruppo Grotte Treviso and Gruppo Speleologico Sacile. This research was realized under the patronage of Società Speleologica Italiana, Federazione Speleologica Regionale del Friuli VeneziaGiulia and Federazione Speleologica Veneta.

\section{REFERENCES}

ARPA FVG, 2006: Rilevamento dello stato dei corpi idrici sotterranei della Regione Friuli Venezia Giulia. Relazione Finale, 22 novembre 2006 (Survey of the Friuli Venezia Giulia Region aquifers conditions. Final Report,22nd November 2006).- Regione Autonoma Friuli Venezia Giulia, [Online] Available from: http://www.regione.fvg.it/rafvg/export/sites/ default/RAFVG/AT9/ARG1/FOGLIA5/modulistica/relazione_totale.pdf

ARPAV, 2007: Atlante delle sorgenti del Veneto (Atlas of the springs of Veneto Region).- pp. 144, Padova.

Behrens, H., Beims, U., Dieter, H., Dietze, G., Eikmann, T., Grummt, T., Hanisch, H., Henseling, H., Käss, W., Kerndorff, H., Leibundgut, C., Müller-Wegener, U., Ronnefahrt, I., Scharenberg, B., Schleyer, R., Schloz, W. \& F. Tilkes, 2001: Toxicological and ecotoxicological assessment of water tracers.- Hydrogeology Journal, 9, 3, 321-325.

Boyer, D.G. \& G.C. Pasquarell, 1999: Agricultural land use impacts on bacterial water quality in a karst groundwater aquifer.- Journal of the American Water Resources Association, 35, 2, 291-300.

Braitenberg, C., Grillo, B., Nagy, I., Zidarich, S., and A. Piccin, 2007: La stazione geodetico-geofisica ipogea del Bus de la Genziana - Pian Cansiglio. (The geodetic - geophysical underground station of Bus de la Genziana - Cansiglio Plateau - Eastern Alps).- Atti e Memorie della Commissione Grotte "E. Boegan", 41, 105-120.

Cabras, S., De Waele, J. \& L. Sanna, 2008: Caves and karst aquifer drainage of Supramonte (Sardinia, Italy): a review.- Acta Carsologica, 37, 2-3, 227-240.
Cancian, G. \& S. Ghetti, 1989: Stratigrafia del Bus de la Genziana (Cansiglio, Prealpi Venete) (Stratigraphy of Bus de la Genziana (Cansiglio, Prealpi Venete)).Studi Trentini Scienze Naturali. Acta Geologica, Trento, 5, 125-140.

Cancian, G., Ghetti, S. \& E. Semenza, 1985: Aspetti geologici dell'Altopiano del Cansiglio (Geological features of the Pian Cansiglio).- Lavori Società veneziana di Scienze naturali, Venezia, Suppl. 10, 79-90.

Castiglioni, G.B., 1964: Forme del Carsismo superficiale dell'Altipiano del Cansiglio (Morphological features of epigean karst of the Pian Cansiglio).- Atti Istituto Veneziano di Scienze Lettere ed Arti, 122, 327-344.

Cavallin, A., 1979: Assetto strutturale del Massiccio Cansiglio-Cavallo (Prealpi Carniche Occidentali) (Structural setting of Cansiglio - Cavallo Massif (Prealpi Carniche Occidentali)).- In: Atti $2^{\circ}$ Convegno di Studi sul Territorio della provincia di Pordenone, Piancavallo, $19^{\text {th }}-20^{\text {th }}$ October $1979,15-32$.

Cucchi, F., Forti, P., Giaconi, M. \& F. Giorgetti, 1998: Note idrogeologiche sulle sorgenti del fiume Livenza (Hydrogeological remarks of Livenza River springs).- In: Atti della Giornata Mondiale dell'Acqua, 23 $3^{\text {rd }}$ March 1998, Roma. Pubblicazione CNR-GNDCI n. 1955.

Ford, D.C., \& P.W. Williams, 2007: Karst Hydrogeology and Geomorphology.- Wiley, pp.576.

Girardi, A. \& V. Toniello, 1983: Su di un indagine geosismica in Pian Code (Altopiano del Cansiglio - Prealpi Venete Orientali) (About a geosismic investigation of Pian code (Altipiano del Cansiglio - Prealpi Venete Orientali)).- In: Atti Convegno Internazionale Carso di Alta Montagna, $30^{\text {th }}$ April $-4^{\text {th }}$ May 1982, Imperia, vol. 1, 121-128. 
Goldscheider, N., Meiman, J., Pronk, M. \& C. Smart, 2008: Tracer tests in karst hydrogeology and speleology.- International Journal of Speleology, 37, 1, 27-40.

Gremaud, V., Goldscheider, N., Savoy, L., Favre, G. \& H. Masson, 2009: Geological structure, recharge processes and underground drainage of a glacierised karst aquifer system, Tsanfleuron-Sanetsch, Swiss Alps.- Hydrogeology Journal, 17, 1833-1848.

Grillo, B., 2007: Contributo alle conoscenze idrogeologiche dell'Altopiano del Cansiglio (Contribution to hydrogeological knowledge of the Pian Cansiglio).- Atti e Memorie della Commissione Grotte "E. Boegan", 41, 5-15.

Jeannin, P.Y., Groves, C. \& Ph. Häuselmann, 2007: Speleological investigations.- In: Goldscheider, N. \& D. Drew (eds.) Methods in Karst Hydrogeology. International Contributions to Hydrogeology. Taylor \& Francis, pp. 25-44, London.

Käss, W., 1998: Tracing technique in geohydrology. Balkema, pp.600, Rotterdam.

Meneghel, M., Sauro, U., Baciga, M.L., Fileccia, A., Frigo, G., Toniello, V. \& D. Zampieri, 1986: Sorgenti carsiche e erosione chimica nelle Prealpi Venete (Karstic springs and chemical erosion in the area of Prealpi Venete).- Studi Trentini di Scienze Naturali, Acta Geologica, 62, 145-172.

Perrin, J. \& M. Luetscher, 2008: Inference of the structure of karst conduits using quantitative tracer tests and geological information: example of the Swiss Jura.Hydrogeology Journal, 16, 5, 951-967.
Prometeo Ricerche per l'Uomo, 2008: www.prometeoricerche.eu.

Riva, A., 2000: Osservazioni geologiche sul Bus della Genziana (1000 V TV) (Geological observations about Bus della Genziana (1000 V TV)).- Speleologia Veneta, 8, 154-156.

Staut, M. \& P. Auersperger, 2006: Tracing of the stream flowing through the cave Ferranova Buža, Central Slovenia.- Acta Carsologica, 35, 83-89.

Toniello, V., 1973: Note sul carsismo profondo dell'altipiano del Cansiglio (Remarks about the deep karst of the Cansiglio plateau).- Bollettino del Museo Veneziano di Storia Naturale, supplemento, 24, 33-41.

Vianelli, M., 2000: Lacqua degli altipiani. La circolazione idrica nell'altopiano dei Sette Comuni e in quello del Cansiglio (The water of the plateau. Groundwater circulation in the Sette Comuni plateau and in the Cansiglio plateau).- In: Vianelli, M. I fiumi della notte. Bollati Boringhieri, pp. 327, Torino.

Vincenzi, V., Gargini, A. \& N. Goldscheider, 2009: Using tracer tests and hydrological observations to evaluate effects of tunnel drainage on groundwater and surface waters in the Northern Apennines (Italy).Hydrogeology Journal, 17, 1, 135-150. 